\title{
The large variation in organic carbon consumption in spring in the East China Sea
}

\author{
C.-C. Chen ${ }^{1}$, G.-C. Gong ${ }^{2,3,4}$, F.-K. Shiah ${ }^{2,5}$, W.-C. Chou $^{2}$, and C.-C. Hung ${ }^{4,6}$ \\ ${ }^{1}$ Department of Life Science, National Taiwan Normal University, 88, Sec. 4, Ting-Chou Rd., Taipei 116, Taiwan \\ ${ }^{2}$ Institute of Marine Environmental Chemistry and Ecology, National Taiwan Ocean University, \\ Keelung 202-24, Taiwan \\ ${ }^{3}$ Center of Excellence for the Oceans, National Taiwan Ocean University, Keelung 202-24, Taiwan \\ ${ }^{4}$ Taiwan Ocean Research Institute, National Applied Research Laboratories, Kaohsiung 852, Taiwan \\ ${ }^{5}$ Research Center for Environment Changes, Academia Sinica, NanKang, Taipei 115, Taiwan \\ ${ }^{6}$ Institute of Marine Geology and Chemistry, and Asia-Pacific Ocean Research Center, National Sun Yat-Sen University, \\ Kaohsiung 804, Taiwan
}

Correspondence to: C.-C. Chen (ccchen@ntnu.edu.tw)

Received: 17 October 2012 - Published in Biogeosciences Discuss.: 20 November 2012

Revised: 31 March 2013 - Accepted: 7 April 2013 - Published: 2 May 2013

\begin{abstract}
A tremendous amount of organic carbon respired by plankton communities has been found in summer in the East China Sea (ECS), and this rate has been significantly correlated with fluvial discharge from the Changjiang River. However, respiration data has rarely been collected in other seasons. To evaluate and reveal the potential controlling mechanism of organic carbon consumption in spring in the ECS, two cruises covering almost the entire ECS shelf were conducted in the spring of 2009 and 2010. These results showed that although the fluvial discharge rates were comparable to the high riverine flow in summer, the plankton community respiration (CR) varied widely between the two springs. In 2009, the level of CR was double that of 2010, with mean $( \pm$ SD) values of $111.7( \pm 76.3)$ and 50.7 ( \pm 62.9$) \mathrm{mg} \mathrm{C} \mathrm{m}^{-3} \mathrm{~d}^{-1}$, respectively. The CR was positively correlated with concentrations of particulate organic carbon and/or chlorophyll $a$ (Chl $a$ ) in 2009 (all $p<0.01$ ). These results suggest that the high CR rate in 2009 can be attributed to high planktonic biomasses. During this period, phytoplankton growth flourished due to allochthonous nutrients discharged from the Changjiang River. Furthermore, higher phytoplankton growth led to the absorption of an enormous amount of fugacity of $\mathrm{CO}_{2}\left(f \mathrm{CO}_{2}\right)$ in the surface waters, even with a significant amount of inorganic carbon regenerated via CR. In 2010, even more riverine runoff nutrients were measured in the ECS than in 2009. Surprisingly,
\end{abstract}

the growth of phytoplankton in 2010 was not stimulated by enriched nutrients, and its growth was likely limited by low water temperature and/or low light intensity. Low temperature might also suppress planktonic metabolism, which could explain why the CR was lower in 2010. During this period, lower surface water $f \mathrm{CO}_{2}$ may have been driven mainly by physical process(es). To conclude, these results indicate that high organic carbon consumption (i.e. CR) in the spring of 2009 could be attributed to high planktonic biomasses, and the lower CR rate during the cold spring of 2010 might be likely limited by low temperature in the ECS. This further suggests that the high inter-annual variability of organic carbon consumption needs to be kept in mind when budgeting the annual carbon balance.

\section{Introduction}

The annual carbon budget is crucial in determining whether a system is a carbon sink or source. This issue is especially important in high productivity coastal and shelf ecosystems, which account for one-fifth to one-third of global marine primary productivity (e.g. Walsh, 1991; Wollast, 1998). However, controversy remains over carbon sinks and sources in coastal and shelf ecosystems due to the complexity of their physical and biogeochemical processes (e.g. de Haas et al., 
2002; Duarte and Agustí, 1998; Walsh et al., 1981). Estimation of the annual carbon budget will depend on the production and consumption of organic carbon, although it also will be affected by other processes, e.g. transporting from terrestrial sources, mixing with other water bodies, benthic processes, etc. Organic carbon production, i.e. primary productivity, has been widely measured at a spatiotemporal scale around the world oceans (e.g. Falkowski and Woodhead, 1992; Thornton, 2012 and citation therein). However, there is relatively little data on the decomposition of organic carbon by plankton respiration (e.g. del Giorgio and Duarte, 2002; del Giorgio and Williams, 2005). Furthermore, highly seasonal and annual variability of organic carbon consumption make it even more difficult to budget the carbon balance (e.g. Chen et al., 2009; Smith and Kemp, 1995).

There is also a controversial debate between carbon sinks or sources in the East China Sea (ECS) ecosystem, one of the largest continental shelves in the world. By using the fugacity of $\mathrm{CO}_{2}\left(f \mathrm{CO}_{2}\right)$, previous studies showed that remarkably high levels of atmospheric $\mathrm{CO}_{2}$ were drawndown into the surface waters of the ECS (Peng et al., 1999; Tsunogai et al., 1999; Wang et al., 2000). A similar result was also observed in summer, with flourishing planktonic activities; however, supersaturated $\mathrm{CO}_{2}$ has regenerated in the subsurface waters below pycnocline in the ECS (Chen et al., 2006; Chou et al., 2009). Therefore, as Chen et al. (2006) propose, whether the ECS shelf acts as a carbon sink or source might depend on the amount of regenerated inorganic carbon in the subsurface waters released through prevailing physical forces. Furthermore, it has also been validated that the organic carbon consumption rate correlates with planktonic activities, which is in turn proportional to the fluvial discharge rate (e.g. Chen et al., 2009). These results also indicate that organic carbon respired by the plankton community serves as an important factor in carbon cycling processes, but may vary seasonally under different physical and biogeochemical conditions. Since most studies on organic carbon consumption in the ECS were performed in summer (Chen et al., 2003, 2006, 2009), studies on other seasons are needed to conclusively reveal the annual carbon budget.

To explore this phenomenon further, data from two spring cruises were used to examine the roles and the potential controlling mechanisms of organic carbon consumption. Plankton community respiration (CR) was taken as the rate of organic carbon consumption in this study. To evaluate this difference, physical and chemical parameters and biological activities were analyzed and compared to elucidate the potential causes for the spatial and inter-annual variations of $\mathrm{CR}$. In addition, the relationship between $\mathrm{CR}$ and $f \mathrm{CO}_{2}$ was examined to reveal the contribution of the plankton community to the $f \mathrm{CO}_{2}$ variation in spring.

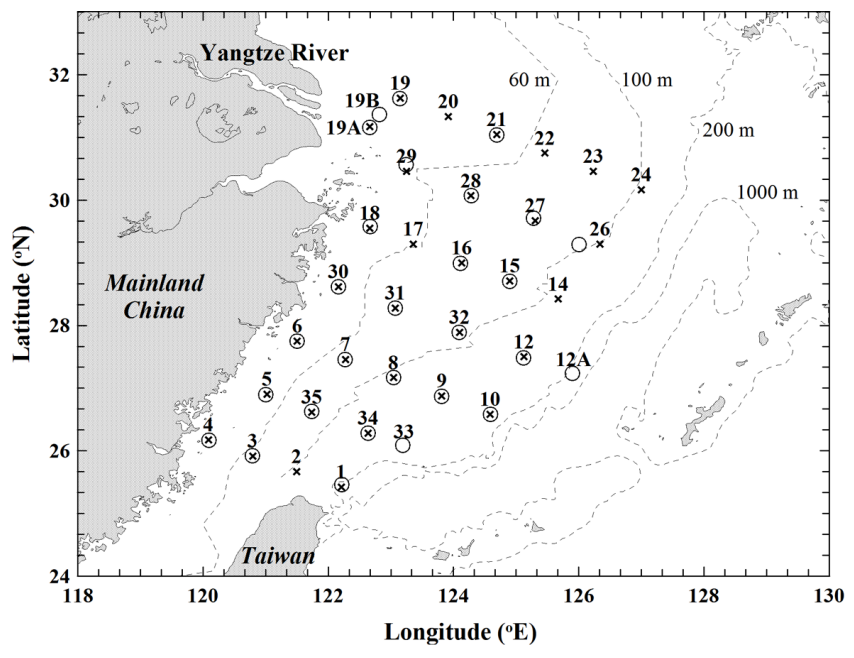

Fig. 1. Map of stations in the spring of $2009(\times)$ and $2010(\bigcirc)$ in the East China Sea (ECS) with the station number above the mark. Bottom depth contours (dashed lines; 60, 100, 200 and $1000 \mathrm{~m}$ ) are also shown; this is also the case in Figs. 2, 3, and 7.

\section{Materials and methods}

\subsection{Study area and sampling}

This study is part of the Long-term Observation and Research of the East China Sea (LORECS) program. Samples were collected on board the R/V Ocean Researcher I, Taiwan, in the spring of 2009 (29 April-10 May) and 2010 (11 April-22 April), with a total of 32 and 28 stations, respectively, in the ECS (Fig. 1). Water samples were collected using Teflon-coated Go-Flo bottles (20 L, General Oceanics Inc., USA) mounted on a General Oceanic rosette assembly (Model 1015, General Oceanics Inc., USA). There were 6 to 9 sampling depths at intervals of 3 to $50 \mathrm{~m}$, depending on the water column depth at each station. Subsamples were taken immediately for further analyses (i.e. nitrate, chlorophyll $a$, and particulate organic carbon) and on-board incubation (i.e. primary production and plankton community respiration).

\subsection{Hydrographic and optical measurements}

Conductivity, temperature, and depth were recorded throughout the water column with a CTD (SBE9/11 plus, Seabird Inc., USA). Photosynthetically active radiation (PAR) was measured throughout the water column with an irradiance sensor ( $4 \pi$; QSP-200L). The depth of the euphotic zone $\left(Z_{\mathrm{E}}\right)$ was taken as the depth of $1 \%$ surface light penetration. The mixed layer depth $\left(M_{\mathrm{D}}\right)$ was based on a 0.125 unit potential density criterion (Levitus, 1982). 


\subsection{Nutrients, chlorophyll $a$, particulate organic carbon, and the fugacity of $\mathrm{CO}_{2}\left(\mathrm{fCO}_{2}\right)$}

Water samples for dissolved inorganic nutrients (e.g. nitrate, phosphate, and silicate) were collected from every sampling depth with $100 \mathrm{~mL}$ polypropylene bottles and were frozen immediately with liquid nitrogen. A custom-made flow-injection analyzer was used for nitrate, phosphate, and silicate analysis with detection limit of $0.3,0.01$, and $0.5 \mu \mathrm{M}$, respectively (Gong et al., 2003). Integrated values for nitrate and other variables in the water column above the $Z_{\mathrm{E}}$ were estimated by trapezoidal method, whereby depth-weighted means were computed from vertical profiles and then multiplied by $Z_{\mathrm{E}}$ (e.g. Smith and Kemp, 1995). Average nitrate concentration over the $Z_{\mathrm{E}}$ was estimated from the vertically integrated value divided by $Z_{\mathrm{E}}$, and this calculation was also carried out with other variables.

Chlorophyll $a$ ( $\mathrm{Chl} a$ ) concentration was measured with a Sea Tech fluorometer attached to the SeaBird CTD for a continuous profile of in vivo fluorescence and calibrated by in vitro fluorometry. Water samples (2L) for in vitro Chl $a$ measurement were immediately filtered through GF/F filter paper (Whatman, $47 \mathrm{~mm}$ ) and stored in liquid nitrogen. The Chl $a$ retained on the GF/F filters was determined fluorometrically (Turner Design 10-AU-005, Parsons et al., 1984). If applicable, Chl $a$ was converted to carbon units using a $\mathrm{C}: \mathrm{Chl}$ value of 52.9, estimated from the shelf waters of the ECS (Chang et al., 2003).

At selected stations, 2L of water samples for particulate organic carbon (POC) were filtered through a Whatman $25 \mathrm{~mm}$ GF/F filter, wrapped in aluminum foil, and then stored at $-20^{\circ} \mathrm{C}$ until analysis. Both the filter and aluminum foil were prebaked at $500^{\circ} \mathrm{C}$ for $2 \mathrm{~h}$. After fuming the filters with $\mathrm{HCl}$, the $\mathrm{POC}$ on the filters was measured using an elemental analyzer (Elementa, Vario EL-III, Germany; Hung et al., 2010).

The fugacity of $\mathrm{CO}_{2}$ in the surface waters was calculated from dissolved inorganic carbon (DIC) and total alkalinity (TA) data using the designed program (Lewis and Wallace, 1998). For details on TA and DIC measurements, refer to Chou et al. (2007).

\subsection{Primary production}

Primary production was measured by the ${ }^{14} \mathrm{C}$ assimilation method (Gong et al., 1999; Parsons et al., 1984). Water samples were collected from three depths within $Z_{\mathrm{E}}$ at selected stations. Samples were prescreened through $200 \mu \mathrm{m}$ woven mesh (Spectrum), and inoculated with $\mathrm{H}^{14} \mathrm{CO}_{3}^{-}$(final conc. $10 \mu \mathrm{Ci} \mathrm{mL}^{-1}$ ) in $250 \mathrm{~mL}$ clean polycarbonate bottles (Nalgene). Samples were incubated on board for $2-4 \mathrm{~h}$ in chambers filled with running surface seawater and illuminated by fluorescent bulbs with a light intensity corresponding to the in situ irradiance levels (Gong et al., 1999). Following retrieval, samples were filtered on GF/F filters and acidified overnight after the addition of $0.5 \mathrm{~mL} 2 \mathrm{~N} \mathrm{HCl}$. Following immersion in $10 \mathrm{~mL}$ of scintillation cocktail (Ultima Gold, Packard), total activity on the filter was counted in a liquid scintillation counter (Packard 2700TR). The results of photosynthesis-irradiance curves were used to calculate primary production for stations, with incubation performed (refer to Gong et al. (1999) for details). To estimate the euphotic zone-integrated primary production at stations where incubation was not performed, an empirical function was applied (please refer to Gong and Liu (2003) for details).

\subsection{Plankton community respiration (CR) and statistical analysis}

The CR was measured as the decrease in dissolved oxygen $\left(\mathrm{O}_{2}\right)$ during dark incubation (Gaarder and Grann, 1927). Incubation was conducted at most of the stations in the ECS, with duplicate samples taken from 2 to 6 discrete depths within $Z_{\mathrm{E}}$ at each station. Treatment samples were siphoned into $300 \mathrm{~mL}$ biological oxygen demand bottles. The treatment involved incubating bottles for $24 \mathrm{~h}$ in a dark chamber filled with running surface water, with maximum temperature changes (mean $\pm \mathrm{SD}$ ) of $1.89 \pm 1.70^{\circ} \mathrm{C}$ and $3.33 \pm 2.52^{\circ} \mathrm{C}$ during each incubations in 2009 and 2010, respectively. Temperature differences between top and bottom of $Z_{\mathrm{E}}$ in all incubation stations were also small with mean $( \pm S D)$ values of $1.58( \pm 1.30)^{\circ} \mathrm{C}$ and $0.91( \pm 1.20)^{\circ} \mathrm{C}$ in 2009 and 2010 , respectively. Concentration of $\mathrm{O}_{2}$ was measured by a direct spectrophotometry method with a precision of $0.02 \mathrm{mg}^{-1}$ (Chen et al., 2007; Pai et al., 1993). The difference in $\mathrm{O}_{2}$ concentration between initial and dark treatment was used to compute the CR (see Chen et al. (2003) for details). To convert respiration from oxygen to carbon units, a respiration quotient (RQ) of 1 was assumed (Hopkinson Jr., 1985; Parsons et al., 1984).

The software SigmaStat (version 3.5, Systat Software, Inc.) was used for the analysis of simple and multiple linear regressions, for analysis of variance (ANOVA), and for the Mann-Whitney Rank Sum test for group comparison.

\section{Results and discussion}

\subsection{Hydrographic patterns in the East China Sea (ECS) in spring}

The ECS shelf ecosystem is strongly influenced by complex and dynamic physical forces, including coastal river discharge, intrusions of the Yellow Sea waters, the Taiwan Strait waters, and the Kuroshio waters as well as the alternating monsoons (e.g. Liu et al., 2003). Regardless of these complexities, a general physical distribution pattern can be observed in the ECS: both surface seawater temperature (SST) and salinity (SSS) increase from the inner shelf toward the slope (Gong et al., 1996; Tseng et al., 2000). Spatially, the variation of SST and SSS is predominantly contributed by 
the coastal river discharge, especially from the Changjiang (aka Yangtze River).

The largest variation of SST and SSS was consistent with periods of high river flow in late spring to early summer in the ECS (Chen et al., 1994; Tseng et al., 2000). High fluvial discharge was also observed in both spring seasons included in this study, and this can be demonstrated in the large area of the Changjiang Diluted Water (CDW; SSS $\leqq 31.0$ ), which is assumed to be an index of riverine runoff (refer to Chen et al., 2009 for details). The area of CDW for $2009\left(23638 \mathrm{~km}^{2}\right)$ and $2010\left(19907 \mathrm{~km}^{2}\right)$ in this study were larger than the mean area of CDW $\left(15604 \mathrm{~km}^{2}\right)$ in summer observed in a previous study (Chen et al., 2009). As expected, the increasing trend of SST and SSS from the inner shelf to the slope was also found in both spring seasons included this study, with the lowest values observed in the Changjiang plume region (Fig. 2). This phenomenon was caused by tremendous fluvial discharge from the Changjiang River, which can be verified from the positively linear relationship between SST and SSS in both study periods (all $p<0.001$ ).

Even with a similar distribution pattern, larger spatial deviations for SST and SSS were observed in 2010 than for 2009 (Table 1; Fig. 2). The values of SST and SSS in 2009 were in the range of $15.7-25.3{ }^{\circ} \mathrm{C}\left(\right.$ mean $\left.\pm \mathrm{SD}=19.4 \pm 2.3^{\circ} \mathrm{C}\right)$ and 27.93-34.53 (mean $\pm \mathrm{SD}=32.61 \pm 1.93$ ), respectively (Table 1; Fig. 2a, b). Their values in 2010 were in the range of 10.6-25.3 ${ }^{\circ} \mathrm{C}\left(\right.$ mean $\left.\pm \mathrm{SD}=16.9 \pm 4.7^{\circ} \mathrm{C}\right)$ and $18.35-34.76$ (mean $\pm \mathrm{SD}=32.20 \pm 3.46$ ), with SST significantly lower in 2010 than in 2009 (Table 1; Fig. 2c, d). It is worth noting that, in 2010, the lowest SSS (18.35) was only observed at St. 19A. However, the mean \pm SD values of SSS in CDW in 2009 and 2010 were similar, with values of $29.27 \pm 0.73$ and $29.24 \pm 1.61$ (St. 19A excluded), respectively. These results all suggest that significant amounts of fresh waters were discharged from China's coast, especially the Changjiang, onto the ECS shelf, and the discharged riverine water was colder during the 2010 study period.

Riverine runoff is usually accompanied by large amounts of dissolved inorganic nutrients and discharged into the shelf ecosystem. In this study, this observation can be validated through the surface contour maps of nitrate, which reveal a similar trend to SSS distribution during both periods, i.e. the nitrate concentration in the surface waters was higher along the inner shelf and nearly depleted in the slope (Fig. 3a, c). A similar spatial pattern was also found for phosphate and silicate in the surface water in this (data not shown) and previous studies (e.g. Gong et al., 1996, 2003). Further analyses show that nitrate concentrations in the surface waters were negatively correlated with SSS in both periods (Fig. 4a; all $p<0.001$ ). These inverse relationships are also found between SSS and phosphate or silicate in the surface waters (Fig. $4 \mathrm{c}$, d; all $p<0.001$ ). These results indicate that nutrients were mixing between riverine water and oceanic water with fluvial runoff as a major nutrient source in the ECS surface plume ecosystem.
Table 1. Range of different variables with mean \pm standard deviation (in parentheses) in surface water $(2-3 \mathrm{~m})$ and averaged values over euphotic depth $\left(Z_{\mathrm{E}} ; \mathrm{m}\right)$ in the ECS in the spring of 2009 and 2010. Surface water variables include water temperature (SST; $\left.{ }^{\circ} \mathrm{C}\right)$, salinity (SSS), and fugacity of $\mathrm{CO}_{2}\left(f \mathrm{CO}_{2} ; \mu \mathrm{atm}\right)$. Variables of averaged value include nitrate $\left(\mathrm{NO}_{3}^{-} ; \mu \mathrm{M}\right)$, phosphate $\left(\mathrm{PO}_{4}^{3-} ; \mu \mathrm{M}\right)$, silicate $\left(\mathrm{SiO}_{4}^{-} ; \mu \mathrm{M}\right)$, chlorophyll $a(\mathrm{Chl} a ; \mathrm{mg}$ $\mathrm{Chl} \mathrm{m}^{-3}$ ), particulate organic carbon (POC; $\mathrm{mg} \mathrm{Cm}^{-3}$ ), primary production (PP; $\mathrm{mg} \mathrm{C}^{-3} \mathrm{~d}^{-1}$ ), and plankton community respiration $\left(\mathrm{CR} ; \mathrm{mg} \mathrm{C} \mathrm{m}{ }^{-3} \mathrm{~d}^{-1}\right)$. Values of $Z_{\mathrm{E}}$ and mixed layer depth $\left(M_{\mathrm{D}} ; \mathrm{m}\right)$ are also shown. In addition, photosynthetically active radiation (PAR; $\mathrm{E} \mathrm{m}^{-2} \mathrm{~d}^{-1}$ ) is provided for reference. The MannWhitney Rank Sum test was applied for variable comparison between 2009 and 2010, and the results are indicated herein.

\begin{tabular}{lll}
\hline $\begin{array}{c}\text { Year } \\
\text { Variables }\end{array}$ & 2009 & 2010 \\
\hline $\mathrm{PAR}$ & $20.6-73.1(60.9 \pm 13.9)$ & $7.7-58.3(34.4 \pm 18.2)^{* *}$ \\
$Z_{\mathrm{E}}$ & $9.0-66.0(35.8 \pm 16.6)$ & $1.0-70.7(28.3 \pm 20.5)$ \\
$M_{\mathrm{D}}$ & $5.0-74.0(20.6 \pm 17.7)$ & $5.0-81.0(31.0 \pm 24.2)$ \\
$\mathrm{SST}$ & $15.7-25.3(19.4 \pm 2.3)$ & $10.6-25.3(16.9 \pm 4.7)^{*}$ \\
$\mathrm{SSS}^{*}$ & $27.93-34.53(32.61 \pm 1.93)$ & $18.35-34.76(32.20 \pm 3.46)$ \\
$f \mathrm{CO}_{2}$ & $130.9-363.4(269.6 \pm 55.3)$ & $199.7-400.3(293.6 \pm 58.4)$ \\
$\mathrm{NO}_{3}^{-}$ & $0.0-25.6(3.6 \pm 5.4)$ & $0.1-59.5(10.1 \pm 13.3)$ \\
$\mathrm{PO}_{4}^{3-}$ & $0.00-0.48(0.10 \pm 0.11)$ & $0.03-2.41(0.39 \pm 0.48) * *$ \\
$\mathrm{SiO} 4$ & $1.8-27.9(6.6 \pm 5.6)$ & $0.8-36.9(8.0 \pm 7.9)$ \\
$\mathrm{Chl} a$ & $0.3-7.9(1.8 \pm 2.0)$ & $0.1-5.9(1.3 \pm 1.1)$ \\
$\mathrm{POC}$ & $83.2-613.8(227.5 \pm 141.9)$ & - \\
$\mathrm{PP}$ & - & $5.9-62.7(17.8 \pm 15.9)$ \\
$\mathrm{CR}$ & $15.2-307.3(111.7 \pm 76.3)$ & $4.2-242.6(50.7 \pm 62.9)^{* *}$ \\
\hline
\end{tabular}

-: no data; *: $p<0.05 ; * *: p<0.001$.

Comparing data of two spring periods, the surface water nitrate was significantly lower in 2009 than in 2010 , with values in the range of undetectable $-25.3 \mu \mathrm{M}$ (mean $\pm \mathrm{SD}$ value $=3.1 \pm 5.8 \mu \mathrm{M}$ ) and undetectable $61.3 \mu \mathrm{M}$ (mean $\pm \mathrm{SD}$ value $=10.5 \pm 14.4 \mu \mathrm{M})$, respectively $(p<0.005$; Fig. 3a, c). The mean value of average nitrate concentration over the euphotic zone in 2009 and 2010 were $3.6 \mu \mathrm{M}$ and $10.1 \mu \mathrm{M}$, respectively ( $p=0.14$; Table 1 ). Interestingly, a previous study showed that the nutrient concentration was positively related to the area of CDW in summer (Chen et al., 2009). Nitrate concentration, however, was relatively lower in 2009, even with the larger CDW area, when compared to 2010. This implies that growth of various plankton communities might be at different stages of bloom between 2009 and 2010 following the intrusion of riverine waters enriched with nutrients and organic matter.

\subsection{Responses of plankton community in spring}

To explore the sequential biological response to fluvial nutrient input, the plankton communities (i.e. biomass and rates) were compared between the spring of 2009 and 2010. In 2009 , the mean values of mixed layer depth $\left(M_{\mathrm{D}}\right)$ and euphotic depth $\left(Z_{\mathrm{E}}\right)$ were $20.6 \pm 17.7 \mathrm{~m}$ and $35.8 \pm 16.6 \mathrm{~m}$, respectively (Table 1 ). The mean value of $M_{\mathrm{D}}$ was smaller 


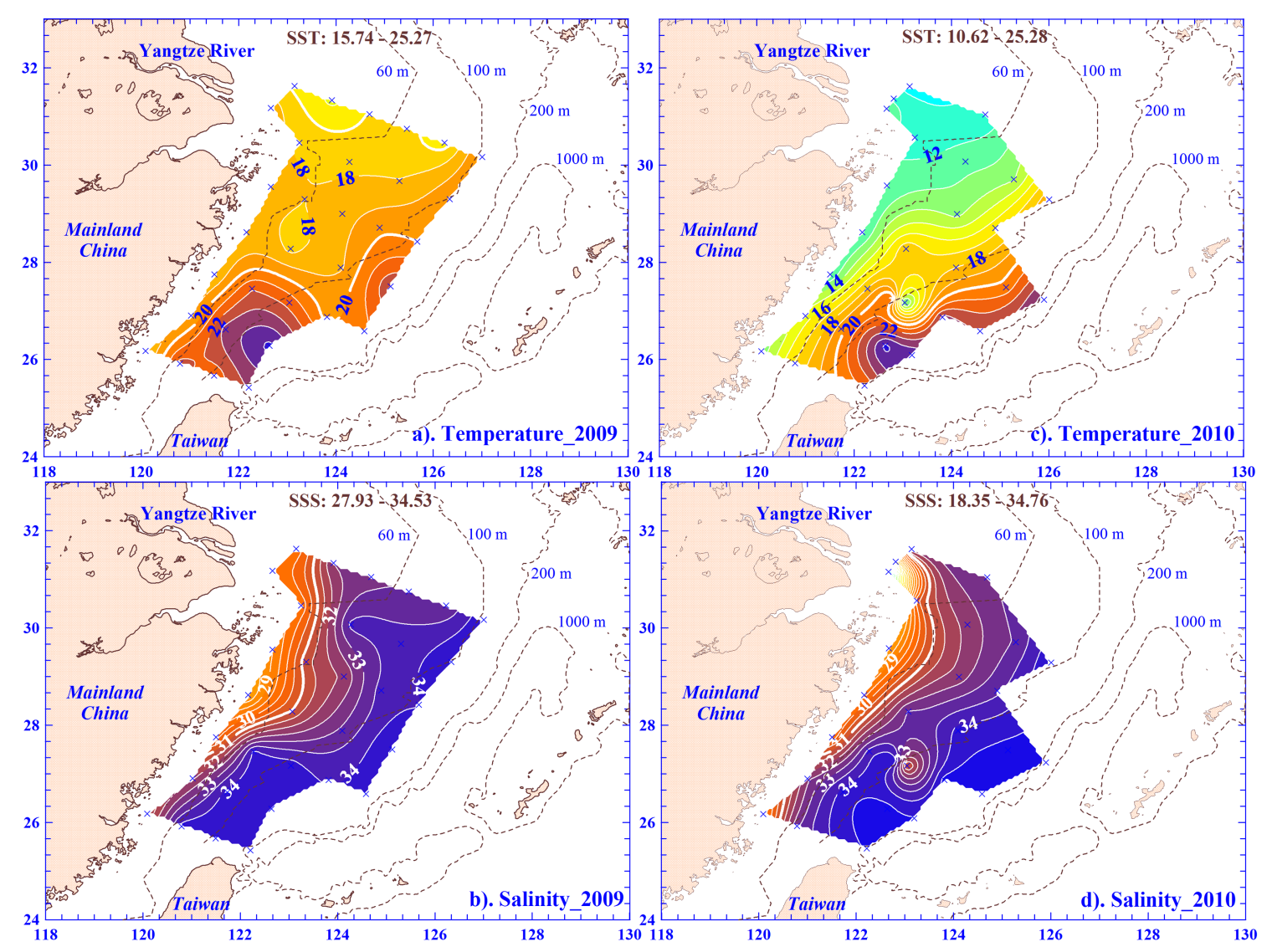

Fig. 2. Contour plots of surface seawater temperature (SST) and salinity (SSS) of the ECS in 2009 (a), (b) and 2010 (c), (d), with contour lines of SST $=20^{\circ} \mathrm{C}$ and SSS $=31$ were bolded for reference. Contour intervals of temperature and salinity are $1^{\circ} \mathrm{C}$ and 0.5 , respectively.

than $Z_{\mathrm{E}}$ in 2009 , but the difference was not statistically significant. The $M_{\mathrm{D}}$ was slightly larger than $Z_{\mathrm{E}}$ in 2010 with mean \pm SD values of $31.0 \pm 24.2 \mathrm{~m}$ and $28.3 \pm 20.5 \mathrm{~m}$, respectively (Table 1). Overall, the $M_{\mathrm{D}}$ was lower than or close to $Z_{\mathrm{E}}$ in this study. For comparison, the biomass and rate of plankton communities were therefore integrated over $Z_{\mathrm{E}}$, since most of them were measured within $Z_{\mathrm{E}}$.

Phytoplankton is one of the major plankton communities and responds instantaneously following intrusion of enriched nutrient diluted water. In the ECS, previous studies found a higher biomass of phytoplankton in the CDW during high riverine flow periods in summer, with a mean value of $3.3 \mathrm{mg} \mathrm{Chl} \mathrm{m}^{-3}$ (Gong and Liu, 2003; Gong et al., 2003). The surface water Chl $a$ showed a similar trend, with the highest value found in the CDW in 2009 of this study (Fig. 3b). The values were in the range of $0.20-10.96 \mathrm{mg}$ $\mathrm{Chl} \mathrm{m}{ }^{-3}$ with a mean $\pm \mathrm{SD}$ value of $1.81 \pm 2.36 \mathrm{mg} \mathrm{Chl} \mathrm{m}^{-3}$ during this period.

The mean Chl $a$ value over the $Z_{\mathrm{E}}$ was almost the same as that of surface water (Table 1). Even though the mean value was not as high as the $3.3 \mathrm{mg} \mathrm{Chl} \mathrm{m}^{-3}$ value observed during the peak summer season, the highest value $(10.96 \mathrm{mg}$

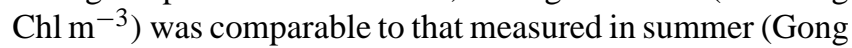

and Liu, 2003; Gong et al., 2003) and in late spring (Hung et al., 2009). Moreover, the Chl $a$ spatial trend was similar to surface water nitrate distribution in the spring of 2009 (Fig. 3a, b). One would therefore expect that the phytoplankton biomass would be associated with available nutrients during this study period. This assumption was confirmed by the positively linear relationship found between Chl $a$ and nitrate concentrations in the surface waters in 2009 (Fig. 5a; $p<0.001)$. It was also supported by linear correlations observed between Chl $a$ and phosphate or silicate concentrations of the surface waters (Fig. $5 b ; p<0.001$ ). In addition to surface water variables, linear regressions were also statistically significant between the averaged values over $Z_{\mathrm{E}}$ of $\mathrm{Chl} a$, on the one hand, and nitrate or silicate concentrations, on the other, in the spring of 2009 (data not shown; $p<0.001$ ). These results all suggest that high phytoplankton biomass might be enhanced by dissolved inorganic nutrients, enriched from the intrusion of riverine water into the ECS in this period (Fig. 5).

The distribution pattern between SSS and nutrients (e.g. nitrate, phosphate, and silicate) was similar in the spring of 2009 and that of 2010 (Figs. 2, 3, and 4a, c, d), and a similar trend was also found between SSS and Chl $a$ in the surface 


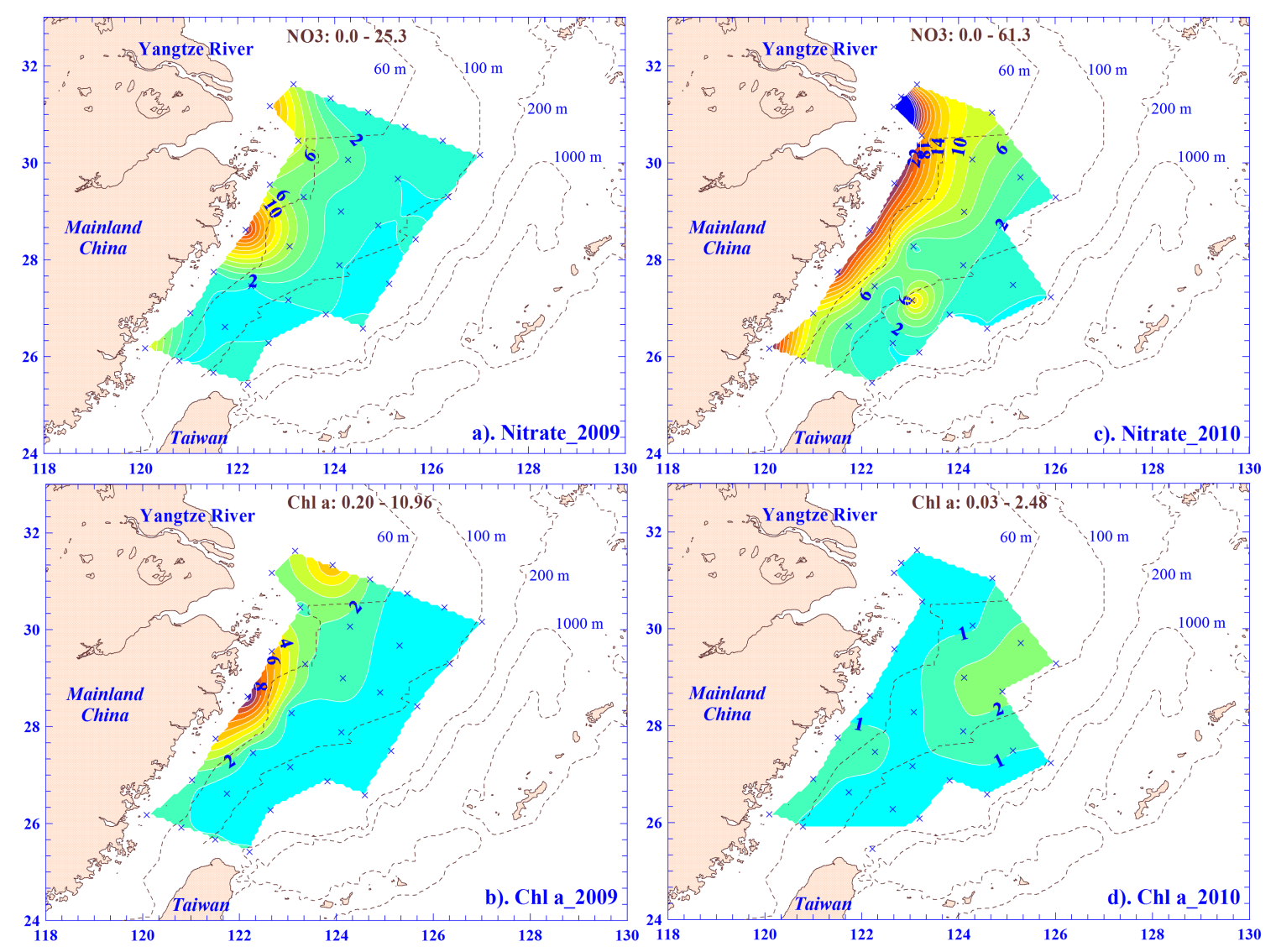

Fig. 3. Contour plots of nitrate and chlorophyll $a$ (Chl $a$ ) in the surface waters of the ECS in 2009 (a), (b) and 2010 (c), (d). The contour intervals of nitrate and $\mathrm{Chl} a$ are $2 \mu \mathrm{M}$ and $1 \mathrm{mg} \mathrm{Chl} \mathrm{m}^{-3}$, respectively.

water in 2009 (Fig. 4b). Surprisingly, the spatial trend was somewhat different in surface water Chl $a$ in 2010, and the higher value was observed in the middle shelf (Fig. 3d). In the spring of 2010, the surface water Chl $a$ value was in the range of $0.03-2.48 \mathrm{mg} \mathrm{Chl} \mathrm{m}^{-3}$ with a mean $\pm \mathrm{SD}$ value of $1.03 \pm 0.72 \mathrm{mg} \mathrm{Chl} \mathrm{m}^{-3}$. Although nitrate concentrations were higher in 2010 than in 2009, both mean Chl $a$ values in the surface waters and averaged over $Z_{\mathrm{E}}$ were relatively low in 2010 compared to 2009. However, this difference was statistically insignificant (Fig. 3b, d; Table 1). This result suggests that nitrate availability might not have limited growth of phytoplankton in the spring of 2010, which can explain why phytoplankton biomass did not increase with nitrate concentration increasing in this period (Fig. 5a). Besides available dissolved inorganic nitrogen, phytoplankton growth limited by phosphate has been observed in the ECS, especially in the CDW (Chen et al., 2004; Gong et al., 1996; Harrison et al., 1990). However, this might not be the case since the mean \pm SD value of phosphate in the surface water in the $\mathrm{CDW}$ was as high as $0.85 \pm 0.77 \mu \mathrm{M}$ in 2010 . Furthermore, the mean molar ratio of N/P in the surface waters was 17.5 for the stations around the CDW regions (e.g. Sts. 19 and 21). These results indicate that dissolved inorganic nutrients may not limit growth of phytoplankton in terms of either availability or N/P molar ratio in 2010, especially in the CDW.

Beyond nutrients, phytoplankton growth may have been regulated by temperature, light intensity, and/or herbivorous grazers. Among the analyzed variables, SST was significantly lower in $2010\left(\right.$ mean $=16.9^{\circ} \mathrm{C}$ ) than that in 2009 (mean $=19.4^{\circ} \mathrm{C}$; Table 1). Moreover, the mean SST was much lower in the CDW region in $2010\left(\right.$ mean $=12.2^{\circ} \mathrm{C}$ ) than in 2009 (mean $=18.0^{\circ} \mathrm{C}$; Fig. 2a, c). To explore this further, Chl $a$ concentrations in the surface waters were positively and negatively correlated, respectively, with SST $<15^{\circ} \mathrm{C}$ and $\geqq 15^{\circ} \mathrm{C}$ in 2010 (Fig. 6). The positive linear regression found in $\mathrm{SST}<15^{\circ} \mathrm{C}$ indirectly showed evidence that the growth of phytoplankton might be limited by cold temperature, but not nutrient availability (mean value $=20.9 \mu \mathrm{M}$; Fig. 5) in 2010 .

In addition to SST and inorganic nutrients, light intensity might be another important factor regulating phytoplankton growth. The mean value of PAR in the water surface in $2010\left(34.4 \mathrm{E} \mathrm{m}^{-2} \mathrm{~d}^{-1}\right)$ was about half of that in 2009 $\left(60.9 \mathrm{E} \mathrm{m}^{-2} \mathrm{~d}^{-1}\right.$; Table $\left.1 ; p<0.001\right)$. This suggests that the lower Chl $a$ in 2010 might be strongly associated with the lower light intensity during this period. The effect of light 

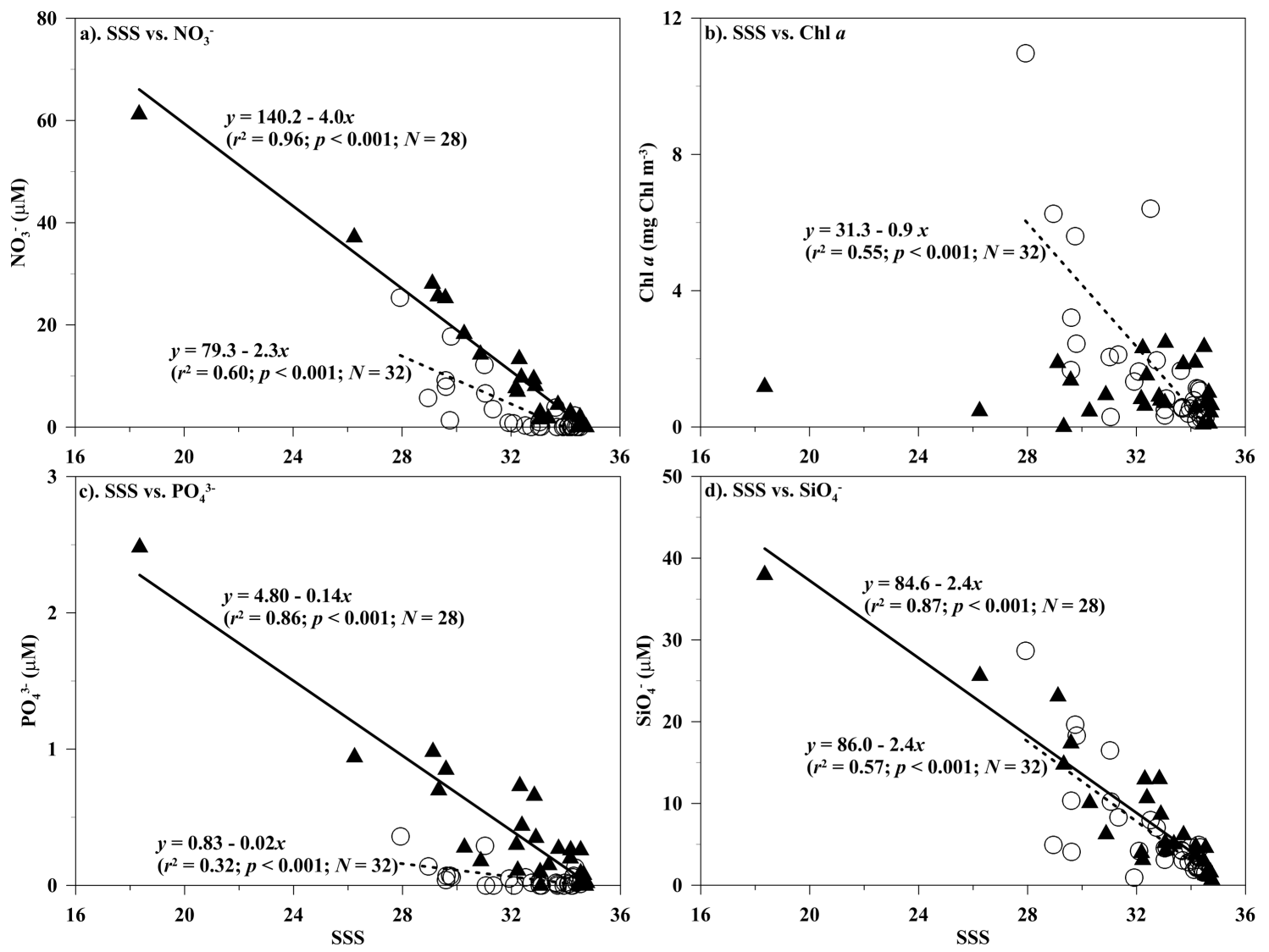

Fig. 4. Relationships between salinity (SSS) vs. (a) nitrate $\left(\mathrm{NO}_{3}^{-}\right)$, (b) chlorophyll $a(\mathrm{Chl} a)$, (c) phosphate $\left(\mathrm{PO}_{4}^{3-}\right)$, and (d) silicate $\left(\mathrm{SiO}_{4}^{-}\right)$ of the surface waters in the spring of 2009 ( $\bigcirc$; dashed lines) and 2010 ( $\boldsymbol{\Delta}$; solid lines) of the ECS. Both $p$ and $r^{2}$ values of linear regression are also shown if statistical significance was evidenced.

intensity on primary production (PP) in aquatic ecosystems is well known, and PP usually increases hyperbolically with an increase in light intensity (Kirk, 1994). As stated above, a previous study showed that the highest PP, seasonally, was observed in summer with mean values of integrated PP and PAR of about $1000 \mathrm{mg} \mathrm{C} \mathrm{m}^{-2} \mathrm{~d}^{-1}$ and $79.9 \mathrm{E} \mathrm{m}^{-2} \mathrm{~d}^{-1}$, respectively (Gong et al., 2003). The mean $( \pm S D)$ values of integrated PP and averaged PP over $Z_{\mathrm{E}}$ were 485.9 $( \pm 571.9) \mathrm{mg} \mathrm{C} \mathrm{m}^{-2} \mathrm{~d}^{-1}$ and $17.8( \pm 15.9) \mathrm{mg} \mathrm{C} \mathrm{m}^{-3} \mathrm{~d}^{-1}$, respectively, in the spring of 2010 (Table 1). This mean integrated PP value was only about half of that observed during the high production season in summer (Gong et al., 2003). Light limitation on phytoplankton growth was even more critical due to a larger $M_{\mathrm{D}}(31.0 \mathrm{~m})$ and smaller $Z_{\mathrm{E}}(28.3 \mathrm{~m})$ in the spring of 2010 (Table 1). To conclude, these results imply that the growth of phytoplankton was limited by both the cold water temperature and low light intensity in spring of 2010. This can explain why the phytoplankton biomass (i.e. $\mathrm{Chl} a$ ) was lower in 2010 than in 2009 although there were more available nutrients in the spring of 2010 (Table 1).

\subsection{High organic carbon consumption in spring 2009}

Plankton community respiration (CR) provides an integrated rate measurement of biotic organic carbon consumption in aquatic ecosystems (Calbet and Landry, 2004; del Giorgio and Duarte, 2002; Hernández-León and Ikeda, 2005; Hopkinson Jr. et al., 1989). Previous studies have shown that the CR was mostly attributed to bacterioplankton and/or phytoplankton, and the contribution by planktonic protozoa was trivial in the ECS (Chen et al., 2003, 2006, 2009). As stated above, the mean Chl $a$ values were relatively higher in 2009 than in 2010, both in the surface waters and in the averaged value over $Z_{\mathrm{E}}$ (Fig. 3b, d; Table 1). Higher CR could therefore be expected for spring 2009 due to the higher phytoplankton biomass. Indeed, the mean value of averaged CR over $Z_{\mathrm{E}}$ in 2009 was double that of 2010, with mean $( \pm \mathrm{SD})$ values of $111.7( \pm 76.3)$ and $50.7( \pm 62.9) \mathrm{mg} \mathrm{C} \mathrm{m}^{-3} \mathrm{~d}^{-1}$, respectively (Table $1 ; p<0.001$ ). The mean averaged CR value in 2009 was comparable to the high rate (i.e. $114 \mathrm{mg}$ $\mathrm{C} \mathrm{m}^{-3} \mathrm{~d}^{-1}$ ) observed during peak planktonic growth in the ECS in summer (Chen et al., 2009). This finding indicates that a huge amount of organic carbon was respired by plankton communities in the spring of 2009. 

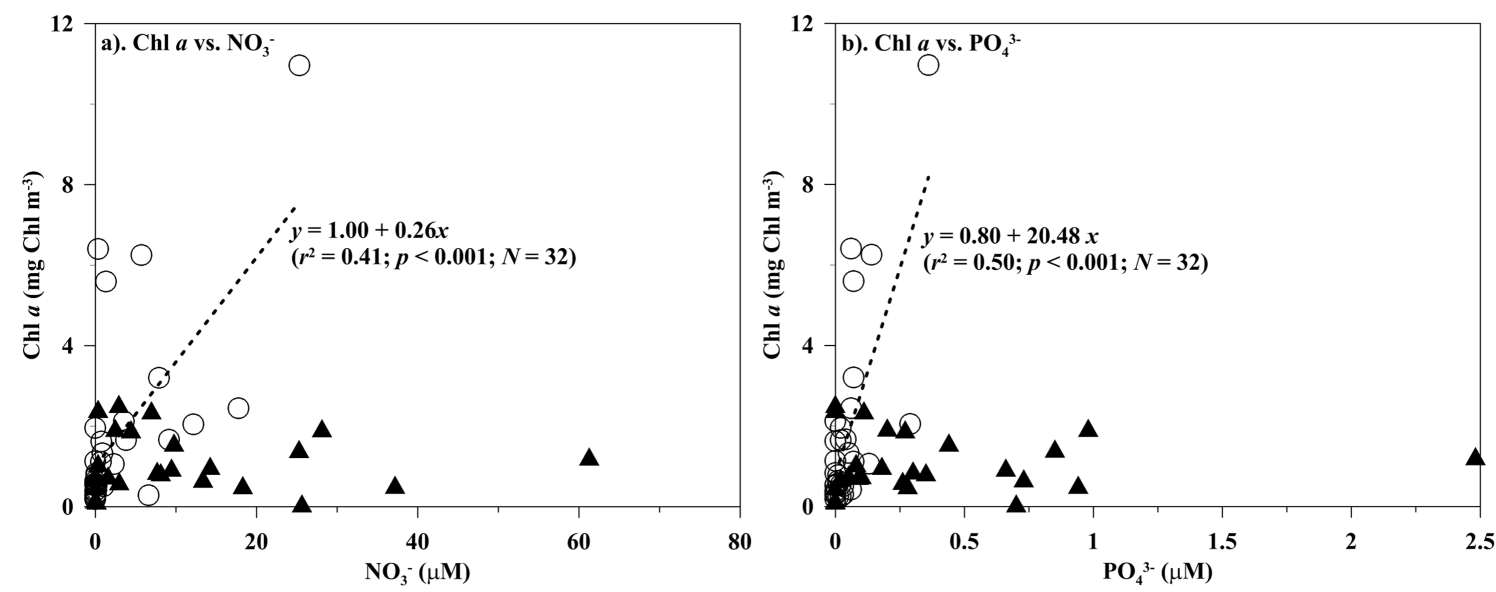

Fig. 5. Relationships between chlorophyll $a(\mathrm{Chl} a)$ vs. (a) nitrate $\left(\mathrm{NO}_{3}^{-}\right)$and $(\mathbf{b})$ phosphate $\left(\mathrm{PO}_{4}^{3-}\right)$ of the surface waters in the spring of 2009 ( ; dashed lines) and $2010(\boldsymbol{\Delta})$ of the ECS. Both $p$ and $r^{2}$ values of linear regression are also shown if statistical significance was evidenced.

The CR contour demonstrates spatial patterns of biotic organic consumption across the entire shelf of the ECS. The $\mathrm{CR}$ in the surface waters ranged from 10.1 to $458.6 \mathrm{mg}$ $\mathrm{C} \mathrm{m}^{-3} \mathrm{~d}^{-1}$ with a mean $( \pm \mathrm{SD})$ value of $132.0( \pm 95.6) \mathrm{mg}$ $\mathrm{C} \mathrm{m}^{-3} \mathrm{~d}^{-1}$ in 2009 (Fig. 7a). Spatially, in 2009, the higher $\mathrm{CR}$ values were mostly along the coast, and surprisingly, in part of the outer shelf of the ECS (e.g. Sts. 9, 10, and 12). The higher CR can be attributed to the higher planktonic biomass; a positive correspondence between CR and phytoplankton biomass or primary production has been observed widely in marine ecosystems (e.g. Jensen et al., 1990; Robinson et al., 2002; Smith and Kemp, 1995). A linear relationship was also apparent between CR and Chl $a$ either in surface waters $\left(r^{2}=0.34 ; p<0.001\right)$ or using averaged values over $Z_{\mathrm{E}}$ $\left(r^{2}=0.25 ; p<0.01\right)$ in this period. The result still holds true when using Chl $a$ expressed in carbon units. Further, phytoplankton respiration was estimated using a biomass specific rate of respiration of 0.25 (Geider, 1992). Results show that of all the CR in the spring of 2009, $23.3 \%$ was contributed by phytoplankton.

Among other plankton communities, bacterioplankton has been recognized as an important component of organic carbon consumption in many aquatic ecosystems (e.g. Chin-Leo and Benner, 1992; del Giorgio and Duarte, 2002; Griffith et al., 1990). Shiah et al. (2000b) estimated that in the ECS, heterotrophic bacterioplankton has completely consumed in situ particulate organic carbon production. Unfortunately, this component was not measured in the present study. However, to examine how CR relates to plankton communities, POC can be assumed to be an indicator of total planktonic biomass. The averaged POC value over $Z_{\mathrm{E}}$ was in the range of $82.2-613.8 \mathrm{mg} \mathrm{C} \mathrm{m}^{-3}$, with a mean $( \pm \mathrm{SD})$ value of $227.5( \pm 141.9) \mathrm{m} \mathrm{C} \mathrm{m}^{-3}$ in 2009 (Table 1). Phytoplankton biomass approximately accounted for $42 \%$ of the mean $\mathrm{POC}$, if $\mathrm{Chl} a$ was expressed per carbon units. Although the mean Chl $a$ value $\left(1.8 \mathrm{mg} \mathrm{Chl} \mathrm{m}^{-3}\right)$ in 2009 was not as high as the mean value $\left(3.3 \mathrm{mg} \mathrm{Chl} \mathrm{m}^{-3}\right)$ observed in summer in previous studies (Table 1; Gong and Liu, 2003; Gong et al., 2003), the POC values in this study were higher than those found in a previous study in summer in the ECS (Chen et al., 2009). Moreover, the high CR rate was linearly regressed with POC both in the surface waters $\left(r^{2}=0.38 ; p<0.001\right)$ and using averaged values over $Z_{\mathrm{E}}\left(r^{2}=0.31 ; p<0.01\right)$ in this period. These results imply that high rates of CR in 2009 were associated with a higher planktonic biomass. The high POC suggested that, in addition to phytoplankton, other plankton communities (e.g. bacterioplankton, protozoan, and zooplankton) might serve as important components contributing to the $\mathrm{CR}$ in this period.

\subsection{Low organic carbon consumption in the spring of 2010}

It was reasonable to expect to observe a lower CR in 2010, since the phytoplankton biomass and SST were lower in this period. Indeed, the rates of CR were significantly lower in 2010 compared to those in $2009(p<0.001$; Table 1); the averaged $C R$ values over $Z_{\mathrm{E}}$ ranged from 4.2 to $242.6 \mathrm{mg}$ $\mathrm{C} \mathrm{m}^{-3} \mathrm{~d}^{-1}$ with a mean $( \pm \mathrm{SD})$ value of $50.7( \pm 62.9) \mathrm{mg}$ $\mathrm{C} \mathrm{m}^{-3} \mathrm{~d}^{-1}$ in the spring of 2010 (Table 1). This mean value was at the lower end of the reported CR values in the ECS and in the coastal shelf as well as in the slope regions (i.e. 2.3-485.3 $\mathrm{mg} \mathrm{C} \mathrm{m}^{-3} \mathrm{~d}^{-1}$ if assuming $\mathrm{RQ}=1$; Biddanda et al., 1994; Chen et al., 2003, 2006, 2009; Williams, 1984). As stated above, a reason for the lower CR might be the lower phytoplankton biomass observed in this period. This hypothesis can be confirmed in the significant linear relationship found between integrated values over $Z_{\mathrm{E}}$ of CR and Chl $a$ in 2010 (data not shown; $r^{2}=0.29 ; p<0.01$ ), but not that of the surface waters and in the averaged values over $Z_{\mathrm{E}}$. 


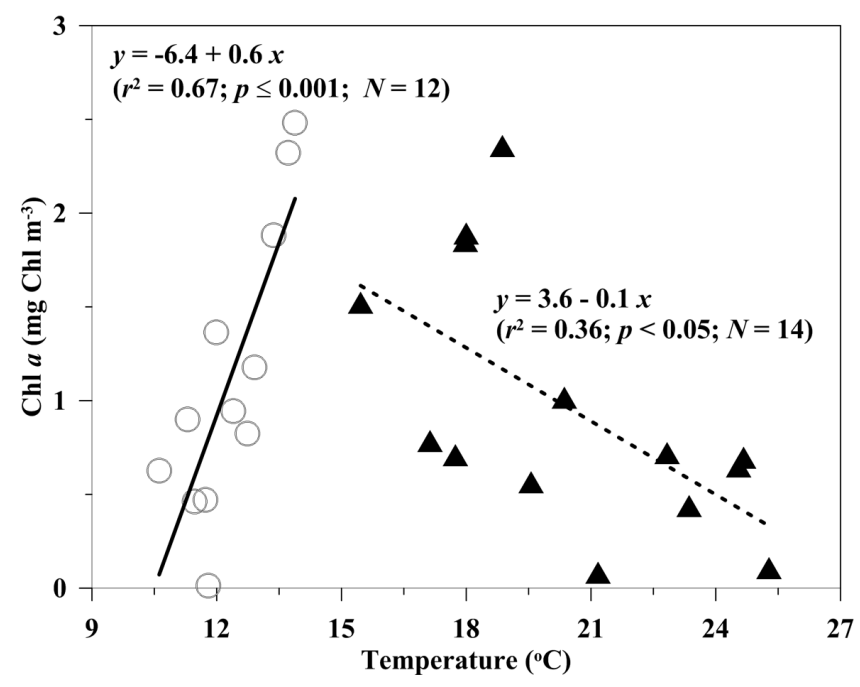

Fig. 6. Relationship between $\mathrm{Chl} a$ and temperature in the surface waters in the spring of 2010. Linear regressions between Chl $a$ vs. temperature $<15^{\circ} \mathrm{C}(\bigcirc$; solid line $)$ or temperature $\geqq 15^{\circ} \mathrm{C}(\boldsymbol{\Lambda}$; dashed line) with $r^{2}$ and $p$ are also shown.

In addition, a linear relationship between the integrated values of CR and PP was also proven for this period (data not shown; $\left.r^{2}=0.89 ; p<0.001\right)$. These results further support the assumption that lower CR observed in 2010 might be related to the low biomass and production of phytoplankton.

Besides phytoplankton, the CR might also have been limited by the lower temperature in the spring of 2010. A limitation of temperature on the growth of bacteria has been found in the ECS, particularly for water temperatures below $20^{\circ} \mathrm{C}$ (Shiah et al., 1999, 2000a). The mean value of SST was $16.9^{\circ} \mathrm{C}$ in the spring of 2010 (Table 1). This indicates that bacterial growth, as well as CR, was potentially confined by the low water temperature. Even though the low temperature limitation on bacterial biomass and production could not be verified, since it was not measured in this study, the temperature limitation on phytoplankton could be indirectly validated from the positively linear relationship between Chl $a$ concentrations and SST $<15^{\circ} \mathrm{C}$ in the surface waters ( $p \leqq 0.001$; Fig. 6 ). Moreover, the integrated CR values were positively linearly regressed with the averaged temperature over $Z_{\mathrm{E}}$ in $2010\left(r^{2}=0.27 ; p<0.01\right)$. These results suggest that the lower CR in 2010 might be due to the low planktonic biomass and the low temperature restriction on the metabolic rates of plankton communities.

To elucidate whether an ecosystem is autotrophic or heterotrophic, the ratio of primary production to respiration $(P / R$ ratio) is applied. In this study, the ratio of integrated values $\left(\mathrm{mg} \mathrm{C} \mathrm{m}^{-2} \mathrm{~d}^{-1}\right)$ of primary production to $\mathrm{CR}$ was used to explore organic carbon utilization between production and consumption in the spring of 2010 in the ECS. The results showed that the $P / R$ ratios were in the range of 0.06 to 2.30 with a mean $( \pm \mathrm{SD})$ value of $0.85( \pm 0.71)$. There were five stations with a $P / R$ ratio $\geqq 1$ (mean value $=1.47$ ), and these stations (Sts. 5, 21, 29, and 30) were mostly in the inner shelf (isobath $\leqq 60 \mathrm{~m}$; Fig. 1; Beardsley et al., 1985), except for St. 28. Interestingly, the lower $P / R$ ratios $(<1)$ were observed mostly in the middle (isobath within 60 $100 \mathrm{~m}$ ) to outer shelves (isobath $>100 \mathrm{~m}$ ) in this period, except for St. 19A. These results suggest that, in the ECS in spring 2010, the inner shelf ecosystem was autotrophic, but the middle to outer shelves were more heterotrophic. Previous studies have also shown that the ECS shelf was a net heterotrophic ecosystem in other seasons (Chen et al., 2003, 2006), except for the inner shelf with high primary productivity ( $>3500 \mathrm{mg} \mathrm{C} \mathrm{m}^{-2} \mathrm{~d}^{-1}$ ). To support the claim that the ECS is net heterotrophic, high bacterial consumption has been suggested and supported by the observation of a tremendous amount of organic carbon discharged from coastal rivers, especially the Changjiang River (Cauwet and Mackenzie, 1993; Chen et al., 2003; Chen and Wang, 1996). However, high CR was not observed during the high riverine discharge period of 2010 (Table 1; Fig. 2c, d).

Bacterial activity might be limited by lower water temperature (mean value $=12.2{ }^{\circ} \mathrm{C}$ in the $\mathrm{CDW}$ region), even with an enormous amount of organic carbon in the inner shelf. This can further explain why an autotrophic ecosystem was still found in this low primary production region. The low $P / R$ ratio (i.e. 0.85 ) in this period was also consistent with previous studies, in which such a low ratio (i.e. $<1$ ) has been widely observed in coastal regions with low primary productivity (e.g. del Giorgio et al., 1997; Duarte and Agustí, 1998).

\subsection{Effect of plankton community respiration on $f \mathrm{CO}_{2}$}

To further understand how organic carbon consumption affects $f \mathrm{CO}_{2}$ dissolved in the surface waters, the relationship between $\mathrm{CR}$ and $f \mathrm{CO}_{2}$ was evaluated. In this study, $f \mathrm{CO}_{2}$ was in the range of $130.9-363.4 \mu \mathrm{atm}$ (mean $\pm \mathrm{SD}=269.6 \pm 55.3 \mu \mathrm{atm}$ ) and 199.7-400.3 $\mu \mathrm{atm}$ (mean $\pm \mathrm{SD}=293.6 \pm 58.4 \mu \mathrm{atm})$ in the spring of 2009 and 2010 , respectively (Table 1 ). The mean value of $f \mathrm{CO}_{2}$ was slightly higher in 2010 than in 2009, even though the SST was higher in 2009 (Table 1). Exploring the absorption of atmospheric $\mathrm{CO}_{2}$ by surface waters in the ECS, Tsunogai et al. (1999) found that $f \mathrm{CO}_{2}$ was positively multiple linear regressed with SST, SSS, and phosphate. Similar multiple regression was also significantly proven for $2009\left(r^{2}=0.74\right.$; $p<0.001$ ); however, a significant relationship was not found for 2010. These results indicate that to estimate $f \mathrm{CO}_{2}$, the empirical function suggested by Tsunogai et al. (1999) might need to be modified, especially during the cold period in the ECS. Furthermore, $f \mathrm{CO}_{2}$ is temperature dependent and should decrease with decreasing temperature (e.g. Goyet et al., 1993; Tsunogai et al., 1999). The mean value of $f \mathrm{CO}_{2}$, however, was higher in the lower SST of 2010 than that in the higher SST of 2009 (Table 1). This result suggests that the lower $f \mathrm{CO}_{2}$ observed in 2009 might have resulted from 


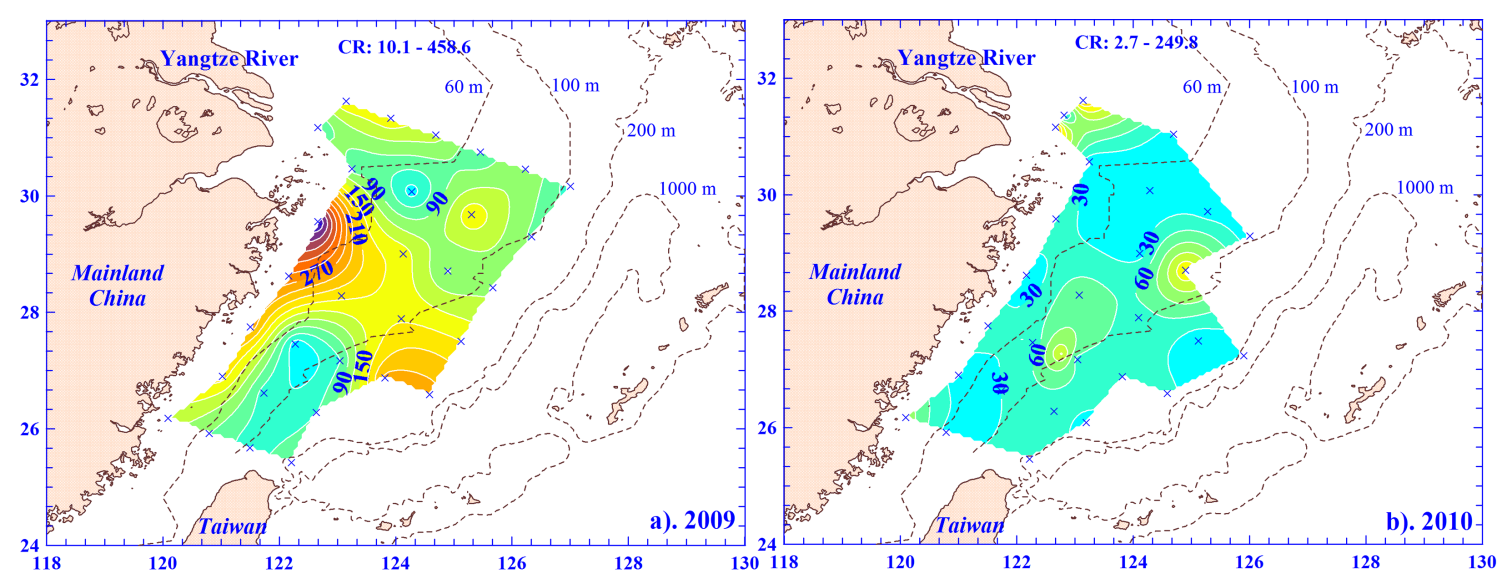

Fig. 7. Contour plots of plankton community respiration (CR) in the surface waters of the ECS in (a) 2009 and (b) 2010 , with a contour interval of $30 \mathrm{mg} \mathrm{C} \mathrm{m}^{-3} \mathrm{~d}^{-1}$.

strong absorption by photosynthesis. Although primary production was not measured in 2009 , this assumption could still be indirectly evaluated from relationships between $f \mathrm{CO}_{2}$ and $\mathrm{Chl} a$, POC, or $\mathrm{CR}$ - particularly $\mathrm{CR}$, which is an integrated response of planktonic activities. To verify this, it was found that $f \mathrm{CO}_{2}$ was indeed negatively linearly regressed against CR in the surface waters in 2009 ( $p<0.05$; Fig. 8a). A similar relationship still held true between $f \mathrm{CO}_{2}$ and the averaged CR over $Z_{\mathrm{E}}$ in $2009(p<0.01)$. The higher CR indicates that planktonic activities were vigorous. The lower $f \mathrm{CO}_{2}$ observed in 2009 implies that more $\mathrm{CO}_{2}$ was absorbed via photosynthesis than that regenerated from CR in regions with higher planktonic activities, and this could also explain the huge deficiency observed between surface water $f \mathrm{CO}_{2}(269.6 \mu \mathrm{atm})$ in 2009 and atmospheric $\mathrm{CO}_{2}$ (approx. $360 \mu \mathrm{atm}$ ). This implication is supported by the negatively linear relationship found between $f \mathrm{CO}_{2}$ and POC in the surface waters of $2009\left(r^{2}=0.43 ; p<0.001\right)$. In addition, surface water $f \mathrm{CO}_{2}$ might also be affected by a significant amount of freshwater discharge into the ECS. To evaluate, the conservative mixing of TA and DIC data between freshwater and seawater end-members were applied. The TA and DIC data reported by Zhai et al. (2007) for the Changjiang River in spring was used as the freshwater endmember data point (both TA and DIC $=1575 \mu \mathrm{mol} \mathrm{kg}^{-1}$ ), whereas the averaged surface data at Sts. 10, 12, 24 and 26 in the spring of 2009 were chosen to represent the seawater end-member $\left(\mathrm{SSS}=34.4, \mathrm{TA}=2279 \mu \mathrm{mol} \mathrm{kg}{ }^{-1}\right.$, and DIC $=1960 \mu \mathrm{mol} \mathrm{kg}{ }^{-1} ;$ W. C. Chou, unpublished data). The result shows that $f \mathrm{CO}_{2}$ varies from 262 to $277 \mu \mathrm{atm}$ within a salinity range between 20 and 34.4, which is relatively small compared to the observed inter-annual variation of $f \mathrm{CO}_{2}$. It also implies that the effect of the Changjiang River discharge on $f \mathrm{CO}_{2}$ in the ECS might be minor in the spring. In addition, these results suggest that there was a strong carbon sink during this study period, especially due to biological uptake.
There was no significant relationship observed between $f \mathrm{CO}_{2}$ and CR or Chl $a$ in surface water for 2010 (Fig. 8a). Further, the $f \mathrm{CO}_{2}$ was regressed against net community production (NCP), i.e. PP-CR, estimated from measured values since the $f \mathrm{CO}_{2}$ should be more directly related to NCP. As expected, a negatively linear relationship was significantly evident between $f \mathrm{CO}_{2}$ and NCP in $2010\left(r^{2}=0.42\right.$; $p<0.001$; Fig. 8b). This relationship, however, became statistically insignificant if two smaller NCP data points, observed from St. 19A, were excluded from this analysis. These results also imply that effect of biological activity on $f \mathrm{CO}_{2}$ might be trivial, especially during a cold period with low primary production. The $f \mathrm{CO}_{2}$ might therefore have been driven mostly by the physical properties (e.g. temperature) of seawater during this period. This can further explain why a heterotrophic ecosystem with a low $\mathrm{P} / \mathrm{R}$ ratio $(0.85)$ would still have a small mean value of $f \mathrm{CO}_{2}(293.6 \mu \mathrm{atm})$. Overall, these results suggest that the relative contribution of planktonic activities and physical processes to shelf carbon cycling in spring might depend on the magnitude of planktonic growth. That is, plankton communities could have a significant impact on surface water $f \mathrm{CO}_{2}$ during flourishing planktonic growth. However, surface water $f \mathrm{CO}_{2}$ might be mostly controlled by physical factor(s) and less influenced by planktonic activities in a cold spring period.

\section{Conclusions}

Previous studies on plankton community respiration (CR) in the East China Sea (ECS) have mostly been conducted in summer, and the rate of $\mathrm{CR}$ is significantly correlated with the fluvial discharge rate (e.g. Chen et al., 2009). To fill the seasonal gap, the present study on organic carbon consumption (CR) was performed in the spring of 2009 and 2010, with stations covering almost the entire ECS shelf, when riverine flows were similar to those in summer, with high flu- 

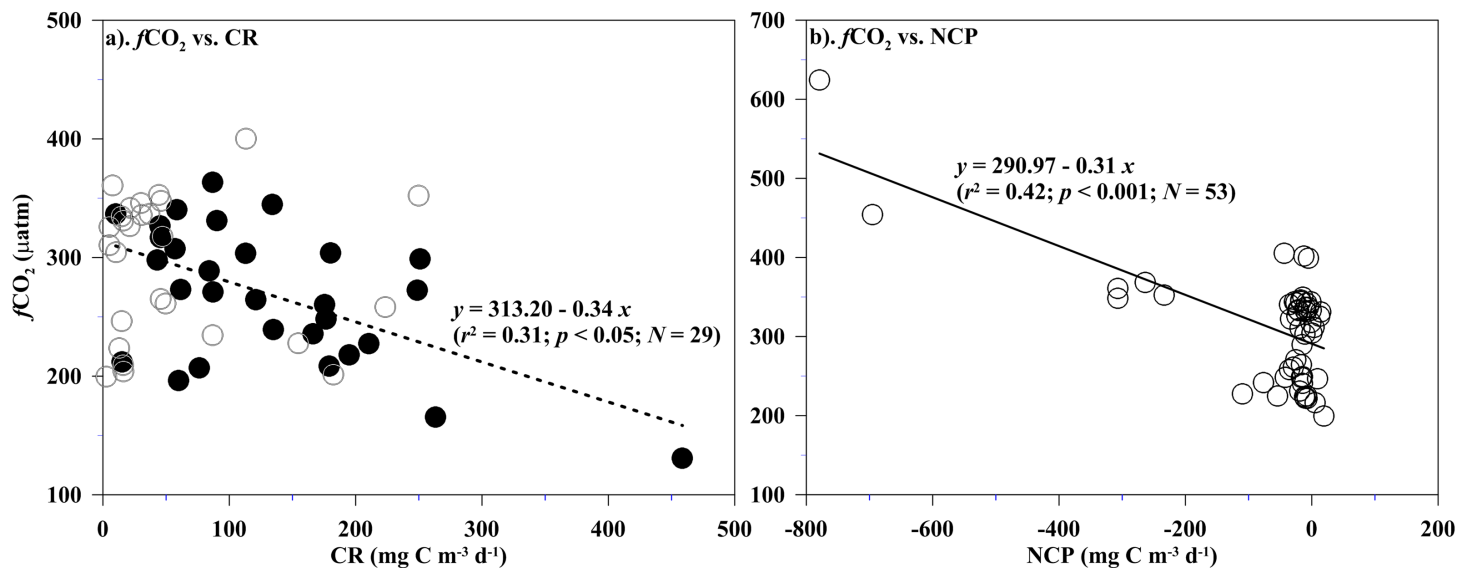

Fig. 8. Relationships between fugacity of $\mathrm{CO}_{2}\left(f \mathrm{CO}_{2}\right)$ vs. (a) plankton community respiration (CR) in the surface waters and (b) net community production $(\mathrm{NCP}=\mathrm{PP}-\mathrm{CR})$ in the spring of $2009(\bullet$; dashed line) and $2010(\bigcirc$; solid line). Primary production was used the measured values where incubation performed. Both $p$ and $r^{2}$ values of linear regression are also shown if statistical significance was evident.

vial discharge. The hydrographic results showed that spatial distribution patterns in temperature (SST) and salinity (SSS) of the surface waters were similar in both springs, i.e. both SST and SSS increased from the inner shelf toward the slope. However, the mean value of SST was significantly lower in $2010\left(16.9^{\circ} \mathrm{C}\right)$ than in $2009\left(19.4^{\circ} \mathrm{C}\right)$.

Spatially, nitrate concentration in the surface waters also revealed a similar trend to SSS distribution in both periods, but the mean value of nitrate was statistically higher in 2010 $(10.5 \mu \mathrm{M})$ than in $2009(3.1 \mu \mathrm{M})$. These results also suggest that nutrients follow a dilution pattern, with riverine runoff as a major nutrient source in the ECS surface plume. Surprisingly, even with higher nitrate concentration, the mean $\mathrm{Chl} a$ value in surface waters was lower in $2010\left(1.03 \mathrm{mg} \mathrm{Chl} \mathrm{m}^{-3}\right)$ compared to $2009\left(1.81 \mathrm{mg} \mathrm{Chl} \mathrm{m}^{-3}\right)$. Further analyses show that the growth of phytoplankton in spring of 2010 might be limited by low water temperature and light intensity, but not by nutrients.

Even though the phytoplankton biomass was slightly higher in 2009, the CR in this period was twice (mean value $=111.7 \mathrm{mg} \mathrm{C} \mathrm{m}^{-3} \mathrm{~d}^{-1}$ ) that of 2010 (mean value $=50.7 \mathrm{mg} \mathrm{C} \mathrm{m}^{-3} \mathrm{~d}^{-1}$ ). This CR rate in 2009 was comparable to the highest rate observed in summer in the ECS (Chen et al., 2006, 2009). Spatially, the higher rates of CR were mostly observed along the coast, an observation which corresponded to the higher $\mathrm{Chl} a$ concentration, suggesting that a remarkable amount of organic carbon consumption was respired by flourishing plankton communities in 2009 . Although no other planktonic biomass was measured in this study, its contribution to CR can be indirectly evidenced from the high particulate organic carbon (mean value $=227.5 \mathrm{mg}$ $\mathrm{C} \mathrm{m}^{-3}$ ) observed in 2009.

Even with the high $\mathrm{CR}$, a huge amount of fugacity of $\mathrm{CO}_{2}$ $\left(f \mathrm{CO}_{2}\right)$ in the surface waters was still drawn down due to vigorous phytoplankton activity in this period. This also can explain why mean $f \mathrm{CO}_{2}$ during the warm spring of 2009 (mean value $=269.6 \mu \mathrm{atm}$ ) was even lower than that in the cold spring of 2010 (mean value $=293.6 \mu \mathrm{atm})$. In contrast, the mean CR value in 2010 was at the lower end of the reported CRs in the ECS and in the coastal shelf, as well as slope regions (e.g. Biddanda et al., 1994; Chen et al., 2003, 2006, 2009; Williams, 1984). The results suggest that the low CR might have been caused by the low biomass and metabolism of plankton, which was suppressed by the low water temperature. During this period, the $f \mathrm{CO}_{2}$ of the surface waters might mainly have been driven by physical processes, and the effect of biological activity on $f \mathrm{CO}_{2}$ could be trivial.

To conclude, these results indicate that the contribution of plankton communities to organic carbon consumption and $f \mathrm{CO}_{2}$ in surface waters could have high inter-annual variability. While planktonic growth is flourishing, the production and consumption of organic carbon by plankton communities could have a significant impact on surface water $f \mathrm{CO}_{2}$. However, surface water $f \mathrm{CO}_{2}$ might be mainly controlled by physical factor(s) and less influenced by planktonic activities in cold periods. The results also suggest that special attention is needed when budgeting annual carbon balances due to this inter-annual variability.

\section{Supplementary material related to this article is available online at: http://www.biogeosciences.net/10/ 2931/2013/bg-10-2931-2013-supplement.pdf.}

Acknowledgements. This study is part of the multidisciplinary Long-term Observation and Research of the East China Sea (LORECS) program, which is supported by the National Science Council, Taiwan, under grant Nos: NSC-98-2611-M-003-001-MY3 
and NSC-101-2611-M-003-003 to C.-C. Chen. The work of G.-C. Gong was partly supported by Center of Excellence for the Oceans, National Taiwan Ocean University. We are furthermore indebted to the officers and crew of the Ocean Researcher I for their assistance. The authors are also grateful to guest editor, H. B. Liu at the Hong Kong University of Science and Technology, and three anonymous reviewers for providing valuable and constructive comments to improve the manuscript.

Edited by: H. Liu

\section{References}

Beardsley, R. C., Limeburner, R., Yu, H., and Cannon, G. A.: Discharge of the Changjiang (Yangtze River) into the East China Sea, Cont. Shelf Res., 4, 57-76, 1985.

Biddanda, B., Opsahl, S., and Benner, R.: Plankton Respiration and Carbon Flux through Bacterioplankton on the Louisiana Shelf, Limnol. Oceanogr., 39, 1259-1275, 1994.

Calbet, A. and Landry, M. R.: Phytoplankton growth, microzooplankton grazing, and carbon cycling in marine systems, Limnol. Oceanogr., 49, 51-57, 2004.

Cauwet, G. and Mackenzie, F. T.: Carbon inputs and distribution in estuaries of turbid rivers: the Yang Tze and Yellow rivers (China), Mar. Chem., 43, 235-246, 1993.

Chang, J., Shiah, F. K., Gong, G. C., and Chiang, K. P.: Cross-shelf variation in carbon-to-chlorophyll $a$ ratios in the East China Sea, summer 1998, Deep-Sea Res. Pt II, 50, 1237-1247, 2003.

Chen, C.-C., Shiah, F.-K., Gong, G.-C., and Chiang, K.-P.: Planktonic community respiration in the East China Sea: importance of microbial consumption of organic carbon, Deep-Sea Res. Pt II, 50, 1311-1325, 2003.

Chen, C.-C., Chiang, K.-P., Gong, G.-C., Shiah, F.-K., Tseng, C.-M., and Liu, K.-K.: Importance of planktonic community respiration on the carbon balance of the East China Sea in summer, Glob. Biogeochem. Cy., 20, Gb4001, doi:10.1029/2005GB002647, 2006.

Chen, C.-C., Gong, G.-C., and Shiah, F.-K.: Hypoxia in the East China Sea: One of the largest coastal low-oxygen areas in the world, Mar. Environ. Res., 64, 399-408, 2007.

Chen, C.-C., Shiah, F.-K., Chiang, K.-P., Gong, G.-C., and Kemp, W. M.: Effects of the Changjiang (Yangtze) River discharge on planktonic community respiration in the East China Sea, J. Geophys. Res., 114, C03005, doi:10.1029/2008jc004891, 2009.

Chen, C. S., Beardsley, R. C., Limeburner, R., and Kim, K.: Comparison of winter and summer hydrographic observations in the Yellow and East China Seas and adjacent Kuroshio during 1986, Cont. Shelf Res., 14, 909-929, 1994.

Chen, C. T. A. and Wang, S. L.: Carbon and nutrient budgets on the East China Sea continental shelf, Biogeochemical processes in the North Pacific, Proceedings of the International Marine Science Symposium 12-14 November, Mutsu, Japan, 169-186, 1996.

Chen, Y.-L.L., Chen, H.-Y., Gong, G.-C., Lin, Y.-H., Jan, S., and Takahashi, M.: Phytoplankton production during a summer coastal upwelling in the East China Sea, Cont. Shelf Res., 24, 1321-1338, 2004.

Chin-Leo, G. and Benner, R.: Enhanced bacterioplankton production and respiration at intermediate salinities in the Mississippi
River plume, Mar Ecol-Prog Ser, 87, 87-103, 1992.

Chou, W. C., Sheu, D. D., Chen, C. T. A., Wen, L. S., Yang, Y., and Wei, C. L.: Transport of the South China Sea subsurface water outflow and its influence on carbon chemistry of Kuroshio waters off southeastern Taiwan, J. Geophys. Res., 112, C12008, doi:10.1029/2007jc004087, 2007.

Chou, W. C., Gong, G. C., Sheu, D. D., Jan, S., Hung, C. C., and Chen, C. C.: Reconciling the paradox that the heterotrophic waters of the East China Sea shelf act as a significant $\mathrm{CO}_{2}$ sink during the summertime: Evidence and implications, Geophys. Res. Lett., 36, L15607, doi:10.1029/2009g1038475, 2009.

de Haas, H., van Weering, T. C. E., and de Stieger, H.: Organic carbon in shelf seas: sinks or sources, processes and products, Cont. Shelf Res., 22, 691-717, 2002.

del Giorgio, P. A. and Duarte, C. M.: Respiration in the open ocean, Nature, 420, 379-384, 2002.

del Giorgio, P. A. and Williams, P. J. le B.: Respiration in aquatic ecosystems, Oxford University Press, New York, 315 pp., 2005.

del Giorgio, P. A., Cole, J. J., and Cimbleris, A.: Respiration rates in bacteria exceed phytoplankton production in unproductive aquatic systems, Nature, 385, 148-151, 1997.

Duarte, C. M. and Agustí, S.: The $\mathrm{CO}_{2}$ balance of unproductive aquatic ecosystems, Science, 281, 234-236, 1998.

Gaarder, T. and Grann, H. H.: Investigations of the production of plankton in the Oslo Fjord. Rapport et Proces-Verbaux des Reunions, Conseil Permanent International pour l'Exploration de la Mer, 42, 3-31, 1927.

Geider, R. J.: Respiration: Taxation without representation?, in: Primary productivity and biogeochemical cycles in the sea, edited by: Falkowski, P. G., and Woodhead, A. D., Plenum Press, New York, 333-360, 1992.

Gong, G.-C. and Liu, G.-J.: An empirical primary production model for the East China Sea, Cont. Shelf Res., 23, 213-224, 2003.

Gong, G.-C., Chen, Y.-L. L., and Liu, K.-K.: Chemical hydrography and chlorophyll $a$ distribution in the East China Sea in summer: implication in nutrient dynamics, Cont. Shelf Res., 16, 15611590, 1996.

Gong, G.-C., Chang, J., and Wen, Y.-H.: Estimation of annual primary production in the Kuroshio waters northeast of Taiwan using a photosynthesis-irradiance model, Deep-Sea Res. I, 46, 93108, 1999.

Gong, G.-C., Wen, Y.-H., Wang, B.-W., and Liu, G.-J.: Seasonal variation of chlorophyll $a$ concentration, primary production and environmental conditions in the subtropical East China Sea, Deep-Sea Res. Pt. II, 50, 1219-1236, 2003.

Goyet, C., Millero, F. J., Poisson, A., and Shafer, D. K.: Temperature dependence of $\mathrm{CO}_{2}$ fugacity in seawater, Mar. Chem., 44, 205-219, 1993.

Falkowski, P. G. and Woodhead, A. D.: Primary production and biogeochemical cycles in the sea, Plenum Press, New York, 545 pp., 1992.

Griffith, P. C., Douglas, D. J., and Wainright, S. C.: Metabolic activity of size-fractionated microbial plankton in estuarine, nearshore, and continental shelf waters of Georgia, Mar. Ecol.Prog. Ser., 59, 263-270, 1990.

Harrison, P. J., Hu, M. H., Yang, Y. P., and Lu, X.: Phosphate limitation in estuarine and coastal waters of China, J. Exp. Mar. Biol. Ecol., 140, 79-87, 1990. 
Hernández-León, S. and Ikeda, T.: A global assessment of mesozooplankton respiration in the ocean, J. Plankton Res., 27, 153-158, 2005.

Hopkinson Jr., C. S.: Shallow-water benthic and pelagic metabolism: evidence of heterotrophy in the nearshore Georgia Bight, Mar. Biol., 87, 19-32, 1985.

Hopkinson Jr., C. S., Sherr, B., and Wiebe, W. J.: Size fractionated metabolism of coastal microbial plankton, Mar. Ecol.-Prog. Ser., 51, 155-166, 1989.

Hung, C.-C., Gong, G.-C., Chiang, K. P., Chen, H. Y., and Yeager, K. M.: Particulate carbohydrates and uronic acids in the northern East China Sea, Estuar. Coast. Shelf Sci., 84, 565-572, 2009.

Hung, C.-C., Gong, G.-C., Chou, W.-C., Chung, C.-C., Lee, M.A., Chang, Y., Chen, H.-Y., Huang, S.-J., Yang, Y., Yang, W.R., Chung, W.-C., Li, S.-L., and Laws, E.: The effect of typhoon on particulate organic carbon flux in the southern East China Sea, Biogeosciences, 7, 3007-3018, doi:10.5194/bg-73007-2010, 2010.

Jensen, L. M., Sand-Jensen, K., Marcher, S., and Hansen, M.: Plankton community respiration along a nutrient gradient in a shallow Danish estuary, Mar. Ecol. Prog. Ser., 61, 75-85, 1990.

Kirk, J. T. O.: Light and photosynthesis in aquatic ecosystems, Cambridge University Press, New York, 509 pp., 1994.

Levitus, S.: Climatological atlas of the word ocean, NOAA professional paper No. 13, US Government Printing Office, Washington, DC, 173 pp., 1982.

Lewis, E. and Wallace, D. W. R.: Program developed for $\mathrm{CO}_{2}$ system calculations, Rep. ORNL/CDIAC-105, Carbon Dioxide Inf. Anal. Cent., Oak Ridge Natl. Lab., Oak Ridege, Tenn., 1998.

Liu, K.-K., Peng, T.-H., Shaw, P.-T., and Shiah, F.-K.: Circulation and biogeochemical processes in the East China Sea and the vicinity of Taiwan: an overview and a brief synthesis, Deep-Sea Res. Pt II, 50, 1055-1064, 2003.

Pai, S.-C., Gong, G.-C., and Liu, K.-K.: Determination of dissolved oxygen in seawater by direct spectrophotometry of total iodine, Mar. Chem., 41, 343-351, 1993.

Parsons, T. R., Maita, Y., and Lalli, C. M.: A manual of chemical and biological methods for seawater analysis, Pergamon Press, New York, 173 pp., 1984.

Peng, T. H., Hung, J. J., Wanninkhof, R., and Millero, F. J.: Carbon budget in the East China Sea in spring, Tellus B, 51, 531-540, 1999.

Robinson, C., Serret, P., Tilstone, G., Teira, E., Zubkov, M. V., Rees, A. P., and Woodward, E. M. S.: Plankton respiration in the Eastern Atlantic Ocean, Deep-Sea Res. I, 49, 787-813, 2002.
Shiah, F.-K., Gong, G.-C., and Liu, K.-K.: Temperature vs. substrate limitation of heterotrophic bacteriaoplankton production across trophic and temperature gradients in the East China Sea, Aquat. Microb. Ecol., 17, 247-254, 1999.

Shiah, F.-K., Liu, K.-K., Kao, S.-J., and Gong, G.-C.: The coupling of bacterial production and hydrography in the southern East China Sea, Cont. Shelf Res., 20, 459-477, 2000a.

Shiah, F.-K., Gong, G.-C., Chen, T.-Y., and Chen, C.-C.: Temperature dependence of bacterial specific growth rates on the continental shelf of the East China Sea and its potential application in estimating bacterial production, Aquat. Microb. Ecol., 22, 155162, $2000 b$.

Smith, E. M. and Kemp, W. M.: Seasonal and regional variations in plankton community production and respiration for the Chesapeake Bay, Mar. Ecol. Prog. Ser., 116, 217-231, 1995.

Thornton, D. C. O.: Primary production in the ocean, in: Advances in Photosynthesis - Fundamental Aspects, edited by: Najafpour, M. M., InTech, Rijeka, Croatia, 563-588, 2012.

Tseng, C., Lin, C., Chen, S., and Shyu, C.: Temporal and spatial variations of sea surface temperature in the East China Sea, Cont. Shelf Res., 20, 373-387, 2000.

Tsunogai, S., Watanabe, S., and Sato, T.: Is there a "continental shelf pump" for the absorption of atmospheric $\mathrm{CO}_{2}$ ?, Tellus $\mathrm{B}, 51$, 701-712, 1999.

Walsh, J. J.: Importance of continental margins in the marine biogeochemical cycling of carbon and nitrogen, Nature, 350, 53-55, 1991.

Walsh, J. J., Rowe, G. T., Iverson, R. L., and McRoy, C. P.: Biological export of shelf carbon is a sink of the global $\mathrm{CO}_{2}$ cycle, Nature, 291, 196-201, 1981.

Wang, S. L., Chen, C. T. A., Hong, G. H., and Chung, C. S.: Carbon dioxide and related parameters in the East China Sea, Cont. Shelf Res., 20, 525-544, 2000.

Williams, P. J. le B.: A review of measurements of respiration rates of marine plankton populations, in: Heterotrophic activity in the sea, edited by: Hobbie, J. E., and Williams, P. J. le B., Plenum Press, New York, 357-389, 1984.

Wollast, R.: Evaluation and comparison of the global carbon cycle in the coastal zone and in the open ocean, in: The Sea, the global coastal ocean, processes and methods, edited by: Brink, K. H. and Robinson, A. R., Wiley, New York, 213-252, 1998.

Zhai, W. D., Dai, M. H., and Guo, X. G.: Carbonate system and $\mathrm{CO}_{2}$ degassing fluxes in the inner estuary of Changjiang (Yangtze) River, China, Mar. Chem., 107, 342-356, 2007. 